\title{
Comparison of mesiodistal tooth widths in Caucasian, African and Japanese individuals with Brazilian ancestry and normal occlusion
}

\author{
Thais Maria Freire Fernandes ${ }^{1}$, Renata Sathler², Gabriela Letícia Natalício ${ }^{3}$,
} José Fernando Castanha Henriques ${ }^{4}$, Arnaldo Pinzan ${ }^{5}$

Objective: To observe the presence of sexual dimorphism and compare the mesiodistal width of the teeth in Caucasian, African and Japanese individuals with Brazilian ancestry not orthodontically treated and with normal occlusion. Methods: One hundred pairs of dental casts were used. It was measured, from first molar to first molar in both arches, the teeth's mesiodistal widths, using a digital caliper. For the statistical analysis of results Kolmogorov-Smirnov, $t$ test, ANOVA and Tukey's test $(p<0.05)$ were used. Results: Sexual dimorphism occurred on the three evaluated groups, and the highest mesiodistal widths were found in males. There was statistically significant difference between racial groups in all evaluated teeth in males. However, in females, this same difference was found only on upper lateral incisor and first molar; and lower lateral incisor, canine, first premolar and first molar. Conclusion: Most of mesiodistal measures present particular characteristics in relation to gender, with higher values for males, and to race, with a tendency for African to present greater mesiodistal distance of the teeth, followed by Japanese and Caucasians, respectively, important for the correct diagnosis and orthodontic planning.

Keywords: Orthodontics. Balanced dental occlusion. Tooth.

Objetivo: observar a presença de dimorfismo sexual e comparar a largura mesiodistal dos dentes em indivíduos brasileiros leucodermas, melanodermas e xantodermas não tratados ortodonticamente e com oclusão normal. Métodos: foram utilizados 100 pares de modelos de gesso ortodônticos. As larguras mesiodistais dos dentes foram medidas de primeiro molar a primeiro molar, em ambas as arcadas, utilizando um paquímetro digital. Para a análise estatística dos resultados foi utilizado o teste de Kolmogorov-Smirnov, o teste $t$, a Análise de Variância (ANOVA) a um critério e o teste de Tukey $(\mathrm{p}<0,05)$. Resultados: ocorreu dimorfismo sexual nos três grupos avaliados, sendo que as maiores larguras mesiodistais foram encontradas no sexo masculino. Houve diferença estatisticamente significativa entre os grupos raciais em todos os dentes avaliados para o sexo masculino. Já no sexo feminino, essa mesma diferença foi encontrada apenas nos dentes incisivo lateral e primeiro molar superior, e incisivo lateral, canino, primeiro pré-molar e primeiro molar inferior. Conclusão: a maioria das medidas dentárias mesiodistais apresentam características próprias em relação ao sexo, com valores maiores para o sexo masculino; e em relação à raça, com uma tendência dos melanodermas apresentarem maior distância mesiodistal dos dentes, seguidos pelos xantodermas e leucodermas, respectivamente. O conhecimento dessas diferenças é importante para o correto diagnóstico e planejamento ortodôntico.

Palavras-chave: Ortodontia. Oclusão dentária balanceada. Dente.

» The authors report no commercial, proprietary or financial interest in the products or companies described in this article.

${ }^{1} \mathrm{PhD}$ and Post-doc in Orthodontics, São Paulo University - Bauru (USP). Head Professor, North Paraná University (UNOPAR).

${ }^{2} \mathrm{MSc}$ and $\mathrm{PhD}$ in Orthodontics, USP/Bauru.

${ }^{3}$ Graduated in Dentistry, USP/Bauru.

${ }^{4} \mathrm{PhD}$ in Orthodontics, USP/Bauru. Full professor, USP/Bauru.

${ }^{5} \mathrm{PhD}$ in Orthodontics, USP/Bauru. Full Professor and Assistant professor,

Pediatric Dentistry Department, Orthodontics and Public Health, USP/Bauru.
How to cite this article: Fernandes TMF, Sathler R, Natalício GL, Henriques JFC, Pinzan A. Comparison of mesiodistal tooth widths in Caucasian, African and Japanese individuals with Brazilian ancestry and normal occlusion. Dental Press J Orthod. 2013 May-June;18(3):130-5.

Submitted: November 24, 2009 - Revised and accepted: April 27, 2011

Contact address: Thais Maria Freire Fernandes

Alameda Octávio Pinheiro Brisolla, 9-75

CEP: 17.012-901 - Bauru/SP - Brazil

E-mail: thaismaria@hotmail.com 


\section{INTRODUCTION}

The dental arch models, part of the orthodontic records, are indispensable for diagnosis and orthodontic planning, being also used for evaluation of treatment and case control. The mesiodistal and vertical widths of the dental crowns and the shape of upper and lower arches enable the correlation of them with the face, besides allow identifying possible alterations of shape. ${ }^{31}$ The measurement of upper and lower mesiodistal dental sizes is an important factor to establish an accurate diagnosis, determine the right treatment plan, and obtain greater stability., ${ }^{6,21}$ The tooth contouring and reshaping, when well indicated and functionally adjusted, can provide satisfactory results. ${ }^{11,26,30}$

The dental size can vary according to gender and race ${ }^{1,16,21}$ becoming necessary new studies that quantify these measures, ${ }^{2}$ for these differences can complicate the orthodontic treatment.

The professionals must be prepared to attend individuals from different ethnicities and be capable to anticipate these differences of size and shape of the dental arch, establishing a more personalized treatment. ${ }^{7}$ Thus, due to the theme's relevance, it was concluded the necessity for a comparison of mesiodistal measures for the different racial groups, constituting appropriated patterns for Caucasian, African and Japanese.

\section{MATERIAL AND METHODS}

\section{Sample composition and criteria for selection}

The sample comprised 100 pairs of dental casts of untreated individuals (50 of each gender) with normal occlusion, harmonious face and mean age of 15.16 years old. The sample was from the division of Orthodontics of the Bauru School of Dentistry and approved by this institution's Ethics Committee. The total was 30 Caucasian individuals (15 of each gender) with mean age of 20.22 years old, 40 African individuals (20 of each gender) with mean age of 13.26 years old and 30 Japanese individuals (15 of each gender) with mean age of 15.71 years old.

The Caucasian group was constituted of Mediterranean descendents; the African, mainly descendents from the African coast; and the Japanese, by individuals Japanese ancestry, and these three samples did not present mixed-race individuals.

The criteria for selection of the sample were: (1) upper and lower permanent teeth in occlusion, being facultative the presence of second and third molars; (2) good occlusion (Angle Class I relationship, with no crowding, no open bite or overbite); (3) absence of previous subjection to orthodontic treatment; (4) absence of teeth with morphology or number anomalies; (5) without extractions; (6) absence of large restorations that could affect the teeth's mesiodistal diameter; (7) models in good conditions and (8) ethnicity verified by photographs and patient's history obtained in surveys filled out by themselves or by their guardians.

\section{Data collection}

After calibration of the examiner, the process of data collection was initiated. The measurements were done directly on the models with the aid of the digital caliper (Mitutoyo, Illinois, USA), enabling to obtain values with accuracy of up to $0.01 \mathrm{~mm}$, measuring the largest mesiodistal measure of incisors, canines, premolars and molars in both sides, in this sequence. The caliper was positioned parallel to the occlusal surface, by the buccal face, perpendicular to the long axis of the crown, measuring the tooth's largest mesiodistal distance.

\section{Statistical analysis}

The data was analyzed through tables and graphics with mean values and standard deviations. The Kolmogorov-Smirnov test proved the normal distribution for all studied variables allowing the use of parametric tests. Thus, for the comparative statistical analysis of the data it were used the following tests: The $t$ test for comparison between genders and ANOVA, for comparison of groups (Caucasian, African, and Japanese) considering a significance level of 5\%. The tests were performed on Statistica for Windows 6.0 (Statistica for Windows 6.0 Copyright StatSoft, Inc. Tulsa, Okla, USA).

\section{RESULTS}

The random errors, obtained through the Dalhberg formula, were considered acceptable and the teeth's mesiodistal distances ranged from 0.09 to $0.33 \mathrm{~mm}$. The molars presented the higher error and the canines the lower. The systematic errors, observed through dependent $t$ test, were considered low and from the 24 evaluated variables only 4 presented statistically significant difference (upper first premolar and molar and lower canine and first premolar). 
The results are presented in tables and figures. Dimorphism between genders occurred in all evaluated groups and the teeth that presented this statistically significant difference can be visualized on Tables 1 , 2 and 3 which compare the mesiodistal measures through $t$ test on African, Caucasians and Japanese, respectively. The racial differences were statistically significant between all variables for the male gender

Table 1 - Comparison of studied variables between genders on the African sample with $t$ test

\begin{tabular}{|c|c|c|c|}
\hline \multicolumn{4}{|c|}{ African } \\
\hline & Male $(n=20)$ & Female $(n=20)$ & \multirow{2}{*}{$p$} \\
\hline & Mean \pm S.D. & Mean \pm S.D. & \\
\hline \multicolumn{4}{|c|}{ Upper teeth } \\
\hline $\mathrm{Cl}$ & $9.05 \pm 0.56$ & $8.63 \pm 0.57$ & $0.024^{*}$ \\
\hline $\mathrm{LI}$ & $7.37 \pm 0.53$ & $7.03 \pm 0.68$ & 0.085 \\
\hline C & $8.26 \pm 0.50$ & $7.73 \pm 0.54$ & $0.003^{*}$ \\
\hline $1 \mathrm{Pm}$ & $7.63 \pm 0.59$ & $7.31 \pm 0.64$ & 0.107 \\
\hline $2 \mathrm{Pm}$ & $7.10 \pm 0.67$ & $6.84 \pm 0.52$ & 0.170 \\
\hline $1 \mathrm{M}$ & $10.96 \pm 0.62$ & $10.22 \pm 0.48$ & $0.000 *$ \\
\hline \multicolumn{4}{|c|}{ Lower teeth } \\
\hline $\mathrm{Cl}$ & $5.61 \pm 0.40$ & $5.25 \pm 0.40$ & $0.009 *$ \\
\hline $\mathrm{LI}$ & $6.33 \pm 0.45$ & $5.97 \pm 0.42$ & $0.012^{*}$ \\
\hline C & $7.44 \pm 0.57$ & $6.86 \pm 0.49$ & $0.001^{*}$ \\
\hline $1 \mathrm{Pm}$ & $7.70 \pm 0.46$ & $7.30 \pm 0.54$ & $0.016^{*}$ \\
\hline $2 \mathrm{Pm}$ & $7.63 \pm 0.57$ & $7.11 \pm 0.60$ & $0.008^{*}$ \\
\hline $1 \mathrm{M}$ & $11.66 \pm 0.49$ & $11.09 \pm 0.58$ & $0.002^{*}$ \\
\hline
\end{tabular}

* Statistically significant for $p<0.05$

Table 2 - Comparison of studied variables between genders on the Caucasian sample by $t$ test

\begin{tabular}{|c|c|c|c|}
\hline \multicolumn{4}{|c|}{ Caucasian } \\
\hline & Male $(n=15)$ & Female $(n=15)$ & \multirow{2}{*}{ p } \\
\hline & MEan \pm S.D. & Mean \pm S.D. & \\
\hline \multicolumn{4}{|c|}{ Upper teeth } \\
\hline $\mathrm{Cl}$ & $8.70 \pm 0.55$ & $8.40 \pm 0.36$ & 0.088 \\
\hline $\mathrm{LI}$ & $6.53 \pm 0.48$ & $6.51 \pm 0.50$ & 0.938 \\
\hline C & $7.82 \pm 0.45$ & $7.54 \pm 0.46$ & 0.110 \\
\hline $1 \mathrm{Pm}$ & $6.86 \pm 0.47$ & $6.89 \pm 0.42$ & 0.842 \\
\hline $2 \mathrm{Pm}$ & $6.60 \pm 0.34$ & $6.56 \pm 0.31$ & 0.739 \\
\hline $1 \mathrm{M}$ & $10.01 \pm 0.39$ & $9.80 \pm 0.55$ & 0.235 \\
\hline \multicolumn{4}{|c|}{ Lower teeth } \\
\hline $\mathrm{Cl}$ & $5.29 \pm 0.29$ & $5.14 \pm 0.21$ & 0.117 \\
\hline LI & $5.81 \pm 0.31$ & $5.71 \pm 0.30$ & 0.381 \\
\hline C & $6.84 \pm 0.33$ & $6.48 \pm 0.33$ & $0.005^{*}$ \\
\hline $1 \mathrm{Pm}$ & $7.05 \pm 0.43$ & $6.85 \pm 0.43$ & 0.219 \\
\hline $2 \mathrm{Pm}$ & $7.04 \pm 0.38$ & $6.90 \pm 0.42$ & 0.356 \\
\hline $1 \mathrm{M}$ & $11.01 \pm 0.77$ & $10.42 \pm 0.57$ & $0.024^{*}$ \\
\hline
\end{tabular}

* Statistically significant for $p<0.05$

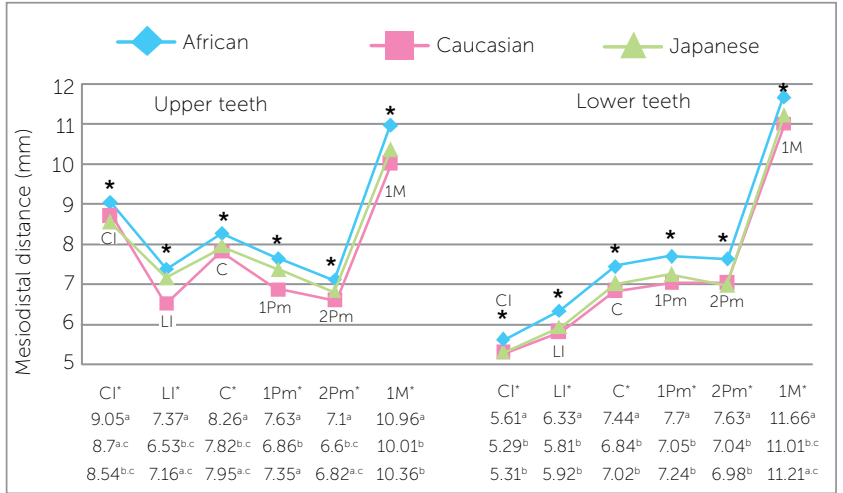

Figure 1 - Comparison of individual values of the studied dental groups (upper and lower teeth) for male gender between the different samples by ANOVA test.

* Statistically significant for $p<0.05$

Different letters on the vertical direction indicate significant difference between groups (Tukey)

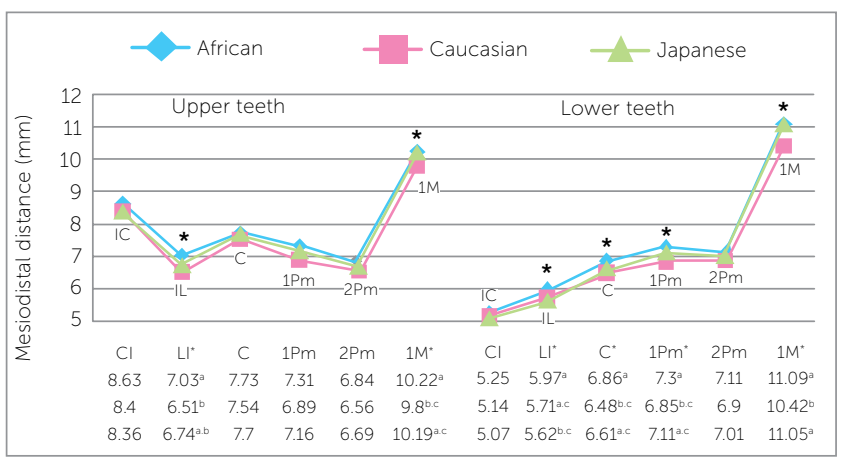

Figure 2 - Comparison of individual values of the studied dental groups (upper and lower teeth) for female gender between the different samples by ANOVA test.

* Statistically significant for $p<0,05$.

Different letters on the vertical direction indicate significant difference between groups (Tukey)

Table 3 - Comparison of studied variables between genders on the Japanese sample by $t$ test

\begin{tabular}{|c|c|c|c|}
\hline \multicolumn{4}{|c|}{ Japanese } \\
\hline & Male $(n=15)$ & Female $(n=15)$ & \multirow{2}{*}{$p$} \\
\hline & Mean \pm S.D. & Mean \pm S.D. & \\
\hline \multicolumn{4}{|c|}{ Upper teeth } \\
\hline $\mathrm{Cl}$ & $8.54 \pm 0.40$ & $8.36 \pm 0.39$ & 0.219 \\
\hline $\mathrm{LI}$ & $7.16 \pm 0.36$ & $6.74 \pm 0.56$ & $0.021 *$ \\
\hline C & $7.95 \pm 0.44$ & $7.70 \pm 0.50$ & 0.166 \\
\hline $1 \mathrm{Pm}$ & $7.35 \pm 0.52$ & $7.16 \pm 0.39$ & 0.274 \\
\hline $2 \mathrm{Pm}$ & $6.82 \pm 0.40$ & $6.69 \pm 0.37$ & 0.376 \\
\hline $1 \mathrm{M}$ & $10.36 \pm 0.57$ & $10.19 \pm 0.41$ & 0.348 \\
\hline \multicolumn{4}{|c|}{ Lower teeth } \\
\hline $\mathrm{Cl}$ & $5.31 \pm 0.35$ & $5.07 \pm 0.22$ & $0.034^{*}$ \\
\hline $\mathrm{LI}$ & $5.92 \pm 0.36$ & $5.62 \pm 0.32$ & $0.019 *$ \\
\hline $\mathrm{C}$ & $7.02 \pm 0.42$ & $6.61 \pm 0.48$ & $0.020 *$ \\
\hline $1 \mathrm{Pm}$ & $7.24 \pm 0.43$ & $7.11 \pm 0.47$ & 0.433 \\
\hline $2 \mathrm{Pm}$ & $6.98 \pm 0.48$ & $7.01 \pm 0.33$ & 0.815 \\
\hline $1 \mathrm{M}$ & $11.21 \pm 0.41$ & $11.05 \pm 0.51$ & 0.340 \\
\hline
\end{tabular}

* Statistically significant for $p<0.05$ 
(Fig 1) and for 6 variables, upper lateral incisor and first molar; and lower lateral incisor, canine, first premolar and first molar, for the female gender (Fig 2) when compared the three groups.

\section{DISCUSSION}

Measurement collection

The orthodontic diagnosis is an essential factor for the elaboration of an adequate treatment plan. Thus, this research had as main objective to determine the dental mesiodistal distances in dental casts, in order to contribute with reasonable information to the orthodontic diagnosis on the different studied races.

In this study, the measurements were performed directly on the casts with digital caliper, because it was already proved that measurements done in study models are more reliable than measurements done directly in the mouth of the patient ${ }^{13}$ and that the caliper is the best way to perform the analysis of dental size for it has more reliability when compared to the EKG caliper. ${ }^{13,24,25}$ Thus, the method used for the measurement of mesiodistal distance of each tooth was obtained by the largest distance between the teeth's mesial and distal faces, through a digital caliper, positioned as parallel as possible to the occlusal surface, by the tooth's buccal face. . $4,17,22,31^{-1}$

\section{Sexual dimorphism}

Several studies have reported the existence of significant differences between men and women's tooth size, with a tendency for men to present larger teeth on mesiodistal direction. ${ }^{2,5,9,15,21,28}$ Therefore, the first caution of this research was to verify the presence of sexual dimorphism within the different racial types. This procedure aimed to determine if it was possible to group the genders in each specific racial group or if there would be the necessity for an individual evaluation, to avoid any gender interferences. Once proven the occurrence of sexual dimorphism between mesiodistal distance in the three analyzed samples (Tables 1, 2 and 3), the two genders were not grouped and it was possible to compare the racial differences, without interference from this factor.

Although in Brazil it occurs a large racial miscegenation of the population, which complicates the accurate establishment of the ethnic origin of the individuals, in this study it was sought to work only with individuals without miscegenation (African, Caucasians and Japanese). In the African group, the male gender presented mesiodistal distances of all teeth larger than the females gender, with nine statistically significant variables (upper central incisors, canines and first molars and all lower teeth) confirming the study by Burris and $\mathrm{Harris}^{7}$ which also found larger teeth for males than for females in African-American individuals.

However, for the other two ethnic groups this difference was not as evident. In Caucasians, only two variables (lower canines and first molars) present statistically significant difference, showing little occurrence of sexual dimorphism (Table 2). But, all dental groups even though not statistically significant presented higher values for men, except for upper first premolar, with mean of $6.86 \mathrm{~mm}$ for males and $6.89 \mathrm{~mm}$ for females.

For Japanese, it occurred sexual dimorphism in four variables (upper lateral incisors; lower central and lateral incisors and canines) as it can be observed on Table 3. Only the lower second premolars were larger in women than in men, despite not statistically significant, with values of 7.01 and $6.98 \mathrm{~mm}$, respectively. It can be said, in general, that the male gender presented larger mesiodistal distances than the female gender, corroborating several authors. ${ }^{4,12,22,27}$

On the three studied racial groups it was possible to notice that there was sexual dimorphism on the lower canine, confirming the studies that indicate the lower canine as the tooth that most presents difference between the male and female genders. ${ }^{20}$ This difference can be used as instrument on the differentiation of genders in Forensic Dentistry. ${ }^{20}$

\section{Ethnic origin}

Many reports in literature emphasize the racial differences, ${ }^{5,10,15,21,28}$ both in the teeth's dimensions and proportions. Therefore, the authors Nie and $\operatorname{Lin}^{19}$ and Ta et $\mathrm{al}^{29}$ suggest to minimize any racial influence, to evaluate individually the different groups, as done in this work. All results obtained on the means of mesiodistal diameters of the groups of teeth in the male gender, when compared the three ethnic groups, presented statistically significant differences (Fig 1). For the female gender, half of the variables presented statistically significant difference (upper lateral incisors and first molars; lower lateral incisors, canines first premolars and first molars), as it can be verified on Figure 2 . 
The individual distances of the teeth in the male gender has a tendency to be larger in most dental groups of the African sample, followed by the Japanese and the lowest values found are related to Caucasians, both in the upper and lower teeth (Fig 1). However, this difference was not so clear in the female gender, which repeated the descending order of mesiodistal distances in African, Japanese and Caucasians, but with comparative results not always significant for each group of teeth (Fig 2).

It is known that Negroids present maxilla and mandible more protruded, ${ }^{8}$ lower and upper incisors more tipped to buccal and more protruded and upper and lower lips more protruded than individuals from different ethnic origins. ${ }^{3,8,18}$ It can be concluded that this double protrusion of teeth can be associated to the larger mesiodistal distance of African as it was found in this study, since the sample was constituted of patients that presented normal occlusion. In the same line of reasoning, it can be concluded that the smaller mesiodistal distances found in Caucasians can be related to the lower tipping normally found in Caucasians. ${ }^{23}$

In the clinical routine, the orthodontist can have trouble when find problems in the dental shape and size. ${ }^{31}$ From the collected data and its analysis, it can be concluded that most mesiodistal measurements present particular characteristics in relation to gender and race, confirming the conclusions by Smith et $\mathrm{al}^{28}$ who observed that the relation between the teeth's size depends on the population, gender and arch length.

Besides, it can be mentioned that the evaluation of the dental size in the clinical behavior can become indispensable on the choice for a tooth to be extracted and on the possible amount of dental stripping, for it can directly affect the treatment planning and prognosis. Thus, confirming the importance of evaluation of dental mesiodistal measurements for the correct diagnosis, orthodontic planning and cases individualization.

\section{CONCLUSION}

The results obtained in this research allowed to conclude that:

1) There is sexual dimorphism on the teeth's mesiodistal distances of male individuals, being greater than in females in:

"African: Lower teeth and upper central incisors, canines and first molars.

"Caucasian: Lower canines and first molars.

" Japanese: Upper lateral incisors and lower central and lateral incisors and canines.

2) There was a tendency for negroids to present greater mesiodistal distance, followed by Japanese and Caucasians, respectively.

3) Most mesiodistal distances presented particular characteristics in relation to gender and race. 


\section{REFERENCES}

1. Almeida RR, Almeida-Pedrin RR, Almeida MR, Insabralde CMB. Tratamento ortodôntico em pacientes com agenesia dos incisivos laterais superiores: integração ortodontia e dentística restauradora (cosmética). J Bras Ortodon Ortop Facial. 2002;7(40):280-90.

2. Arya BS, Savara BS, Thomas D, Clarkson Q. Relation of sex and occlusion to mesiodistal tooth size. Am J Orthod. 1974;66(5):479-86.

3. Bacon W, Girardin P, Turlot JC. A comparison of cephalometric norms for the African Bantu and a Caucasoid population. Eur J Orthod. 1983;5(3):233-40.

4. Bishara SE, Fernandez Garcia A, Jakobsen JR, Fahl JA. Mesiodistal crown dimensions in Mexico and the United States. Angle Orthod. 1986;56(4):315-23.

5. Bishara SE, Jakobsen JR, Abdallah EM, Fernandez Garcia A. Comparisons of mesiodistal and buccolingual crown dimensions of the permanent teeth in three populations from Egypt, Mexico, and the United States. Am J Orthod Dentofacial Orthop. 1989;96(5):416-22

6. Bolton WA. The clinical application of tooth-size analysis. Am J Orthod Dentofacial Orthop. 1962;48(7):504-29

7. Burris BG, Harris EF. Maxillary arch size and shape in American blacks and whites. Angle Orthod. 2000;70(4):297-302.

8. Freitas LM, Pinzan A, Janson G, Freitas KM, Freitas MR, Henriques JF. Facial height comparison in young white and black Brazilian subjects with normal occlusion. Am J Orthod Dentofacial Orthop. 2007:131(6):706.e1-6.

9. Doris JM, Bernard BW, Kuftinec MM, Stom D. A biometric study of tooth size and dental crowding. Am J Orthod. 1981;79(3):326-36.

10. Freeman JE, Maskeroni AJ, Lorton L. Frequency of Bolton tooth-size discrepancies among orthodontic patients. Am J Orthod Dentofacial Orthop. 1996;110(1):24-7.

11. Furquim IZ, Suguino R, Sábio SS. Integração Ortodontia-Dentística no tratamento da agenesia bilateral dos incisivos superiores: relato de um caso clínico. Rev Dental Press Ortod Ortop Facial. 1997;2(5):10-33

12. Hattab FN, al-Khateeb S, Sultan I. Mesiodistal crown diameters of permanent teeth in Jordanians. Arch Oral Biol. 1996:41(7):641-5

13. Hunter WS, Priest WR. Errors and discrepancies in measurement of tooth size. J Dental Res. 1960;39:405-14

14. Keene A, Engel G. The mandibular dental arch, part IV: prediction and prevention of lower anterior relapse. Angle Orthod. 1979;49(3):173-80.

15. Lavelle CL. Maxillary and mandibular tooth size in different racial groups and in different occlusal categories. Am J Orthod. 1972;61(1):29-37.

16. Macko DJ, Ferguson FS, Sonnenberg EM. Mesiodistal crown dimensions of permanent teeth of black Americans. ASDC J Dent Child. 1979;46(4):314-8

17. Moorrees CF, Reed RB. Biometrics of crowding and spacing of the teeth in the mandible. Am J Phys Anthropol. 1954;12(1):77-88
18. Naidoo LC. Miles LP. An evaluation of the mean cephalometric values for orthognathic surgery for black South African adults. Part 1: Hard tissue. J Dent Assoc S Afr. 1997:52(9):545-50.

19. Nie Q, Lin J. Comparison of intermaxillary tooth size discrepancies among different malocclusion groups. Am J Orthod Dentofacial Orthop. 1999;116(5):539-44.

20. Pettenati-Soubayroux I, Signoli M, Dutour O. Sexual dimorphism in teeth discriminatory effectiveness of permanent lower canine size observed in a XVIIIth century osteological series. Forensic Sci Int. 2002;126(3):227-32.

21. Richardson ER, Malhotra SK. Mesiodistal crown dimension of the permanent dentition of American Negroes. Am J Orthod. 1975;68(2):157-64.

22. Santoro M, Ayoub ME, Pardi VA, Cangialosi TJ. Mesiodistal crown dimensions and tooth size discrepancy of the permanent dentition of Dominican Americans. Angle Orthod. 2000;70(4):303-7.

23. Sathler RC. Estudo comparativo do padrão cefalométrico de jovens mestiços nipo-brasileiros: grandezas dentárias e esqueléticas [tese]. Bauru (SP): Universidade de São Paulo; 2009

24. Schirmer UR, Wiltshire WA. Manual and computer-aided space analysis: a comparative study. Am J Orthod Dentofacial Orthop. 1997;112(6):676-80.

25. Shellhart WC, Lange DW, Kluemper GT. Hicks EP, Kaplan AL. Reliability of the Bolton tooth-size analysis when applied to crowded dentitions. Angle Orthod. 1995:65(5):327-34

26. Sinclair PM, Little RM. Dentofacial maturation of untreated normals. Am J Orthod. 1985:88(2):146-56

27. Singh SP, Goyal A. Mesiodistal crown dimensions of the permanent dentition in North Indian children. J Indian Soc Pedod Prev Dent. 2006:24(4):192-6.

28. Smith SS, Buschang PH, Watanabe E. Interarch tooth size relationships of 3 populations: "does Boltons analysis apply?". Am J Orthod Dentofacial Orthop. 2000;117(2):169-74.

29. Ta TA, Ling JY, Hagg U. Tooth-size discrepancies among different occlusion groups of southern Chinese children. Am J Orthod Dentofacial Orthop. 2001:120(5):556-8.

30. Woodworth DA, Sinclair PM, Alexander RG. Bilateral congenital absence of maxillary lateral incisors: a craniofacial and dental cast analysis. Am J Orthod. 1985:87(4):280-93.

31. Yamaguto $O$, Vasconcelos M. Determinação das medidas dentárias mésiodistais em indivíduos brasileiros leucodermas com oclusão normal. Rev Dental Press Ortod Ortop Facial. 2005;10(5):99-107. 